\title{
TRIM21 wt Allele
}

National Cancer Institute

\section{Source}

National Cancer Institute. TRIM21 wt Allele. NCI Thesaurus. Code C94753.

Human TRIM21 wild-type allele is located in the vicinity of $11 \mathrm{p} 15.5$ and is approximately 9 $\mathrm{kb}$ in length. This allele, which encodes E3 ubiquitin-protein ligase TRIM21 protein, plays a role in the regulation of both cell cycle progression and ubiquitinylation of proteins.

Polymorphism of the gene is associated with systemic lupus erythematosus. 